\title{
THE CRAZY FLIGHT PHENOMENON OF THE RUFFED GROUSE
}

by Victor C. Friesen, Rosthern, Saskatchewan

On our farm, three miles east of Rosthern, Saskatchewan, I have had numerous opportunities to observe Ruffed Grouse (Bonasa umbellus). Immediately east of the farmyard are two mature aspen poplar bluffs, each of approximately two acres in extent. These bluffs have an undergrowth which consists chiefly of red osier dogwood with some prickly rose, northern gooseberry, and choke-cherry - altogether an ideal habitat for Ruffed Grouse. A row of pruned Manitoba maples leads from the bluffs across the yard to a wooded pasture on the other side. The grouse frequently walk along the tree-row when seeking a different covert.

Every year from my boyhood days in the 1930's to the present time, I have heard cock grouse drumming in one of the bluffs, and I have often seen a hen with her covey of chicks. However, it is only during the past decade that I have observed the Ruffed Grouse's "crazy flight", the phenomenon which I wish to consider here at length. The "crazy flight" refers to this bird's propensity for flying wildly into strange territory at certain times of the year, particularly autumn, and/or flying against objects such as trees and buildings, thereby often seriously injuring, if not killing, itself. Reports have been made of this grouse hurtling against automobiles and through plate glass windows, and in one instance of its being impaled on a dry branch. The bird's reckless flight has been noted by many observers, and several explanations of it have been offered.

Audubon (1838) in October, 1820, observed the grouse's "partial sorties" (1967:73) with the approach of autumn, most noticeable where the birds cross rivers. He suggested that an abundance of food was a cause of these flights. He also noted that the male grouse was readily "inflamed with jealousy" (1967:77) when a sound was produced in imitation of the grouse's drumming, causing the bird to fly directly at the imitator.

Later observers seem to have taken up suggestions from Audubon's report to explain the crazy flight phenomenon. There is, for example, an old hunter's notion analogous to the "psychological" motive seen by Audubon in the jealous grouse. This notion is that Ruffed Grouse are frightened by the falling of leaves in autumn, their habitat being now more exposed, and that the birds become so nervous and distracted that they embark on their crazy flights.

Allen (1928) indicated that fright (although not from falling leaves) accounted for the unusual flights of Ruffed Grouse. Some birds had appar. ently been pursued by owls or hawks; others had apparently been frightenea by wind storms; in some cases the cause of fright was "indeterminable" (1928:85). The author also pointed to a parasitic stomach worm as a possible irritant which could prompt wild flights, since a considerable percentage of the birds were thus infected. Gross (1925) stated that seven of 10 birds found dead contained nematode stomach worms (Dispharynx). And a blood-sucking fly has been cited elsewhere (Hall, 1946) as a possible irritant initiating crazy flight.

Bump and his associates (1947) noted that a Ruffed Grouse marked by attaching a bell to its wing was found later with a broken neck, having flown against a tree. The suggestion was that the bird, irritated by the bell, responded similarly to a bird irritated by a parasite. Bump and associates believed that the crazy flight phenomenon, however, was largely the result of young birds seeking territories each fall. This notion is a refinement of what Audubon had earlier called "partial sorties." Of 15 casualties examined 
by the Conservation Department's field crews, all were first-year birds. Such a movement helps disperse young birds and the dispersal is generally effective, according to this study, since the chance of many birds flying into obstructions seems "quite remote." Of more than 50,000 grouse flushes witnessed by the field crews, less than half a dozen resulted in accidental deaths. The crews also reported grouse deaths by collision in spring, but these were thought to be merely accidental and not due to a crazy flight impulse.

Schorger (in Grange, 1948) believes that in Wisconsin spring crazy flights, although comparatively rare, do occur. $\mathrm{He}$ would agree with the New York State study that population pressure appears to be the cause of the flightsspring or fall. A peak occurs in fall, he believes, because of the greater activity of the grouse then. He also records two peaks during a single day - in the morning and in the evening. Of the casualties which Grange (1948) examined, all had been normal, healthy birds, thus discounting the parasite theory.

Forbush (1927), cites Seton, who claimed that the crazy flight was a characteristic of young birds in their first season and sometimes in the second. Forbush himself, however, suggested that the flight might be caused by an "inherited instict of migration." Bent (1932) repeats this notion.

Hall (1946) says that if Ruffed Grouse are following an old migratory instinct, then there should be a southward drift of the birds, which is apparently not the case. Hall suggests -and this harks back again to another of Audubon's conclusions - that the grouse may be prompted into crazy flights by an unconscious urge to change diet.

Another interesting theory is that grouse engage in wild flying because they have eaten mouldy or fermented rose hips. It is claimed that such birds are inebriated and cainot sie what they fly into. Attractive as this theory may sound, it does not appear to be substantiated by much evidence. Both the New York and the Wisconsin studies show that rose hips are not a principal food item of grouse. Indead, of 1093 grouse examined in New York in all seasons from 1931 to 1941, rose hips were not among the top 25 plant foods.

Edminster (1947) provides us with one of the most detailed explanations of the crazy flight phenomenon. Young Ruffed Grouse become quarrelsome as they attain sexual maturity in fall. A bird may be driven away sy a membe: of its own brood, and its flight may be reckless as it seeks to flee its tormentor. This bird must find a territory elsewhere, but it may encounter further hostility from other grouse already established there. With continued harassment, the grouse will become "more nervous" and "more desperate" because of its "growing inferiority complex." It will thus fly out of its normal habitat, and on occasions, fly against objects in those unfamiliar surroundings.

My observations at our farm during the 1960's of six incidents involving Ruffed Grouse crazy flights tend not to point to any clear-cut reason for the accidents. More occurred in springrather than in fall as one might expect - and one occurred in summer. Most cccurred in the waning light of early evening when grouse commonly seek their nightime covert; one occurred on a sunny midmorning; another occurred in the afternoon. All collisions were against the house rather than against one of the other buildings. (I would, of course, be more aware of collisions with the house.) Where the point of impact could be determined (in three cases), it was found to be only one to two feet above the ground.

The six incidents may not form a representative sample of the crazy flight phenomenon, but my opportunity to make this number of observations in as many years is noteworthy. An experienced Saskatchewan birder with whom I consulted was not familiar with the phenomenon, and Grange (1948) mentions that in 25 years' experience with grouse in Wisconsin he examined only about half a dozen crazy grouse. 
My first observation took place towards the end of April, 1963 when I found a dead Ruffed Grouse beside the house. It had a broken neck, and I assumed that it had flown against the wall. A few days later, in the evening, I heard a loud thump against the house's outer wall. On going outside, I discovered beside the house a freshly killed grouse with a broken neck. A few feathers still sticking to the wall showed where the bird had met its death. Both incidents were witnessed by another member of the family.

The next year, 1964, two more grouse struck the house. The first of these casualties was similar in nature to the last one described, except that the time of year was early May and the time of day was midmorning. Again, a thump was heard on an outer wall, and the dead bird was found nearby. On the wall where the thump originated could be seen a mark as though a dusty mop had been beaten there.

The second incident that year occurred on an afternoon in August. It is the only incident in which I could observe the complete flight of the bird. I was standing outside near the doorway talking to two guests, when I noticed a Ruffed Grouse 35 yards away, walking towards us beneath the row of Manitoba maples which skirt one side of the yard. I had barely pointed out the grouse's presence to my companions before the bird rocketed into flight almost directly at us. Immediately I flailed my arms to attract the bird's attention. It veered at the last moment so that it struck the house only a glancing blow. It plumped into the grass beside us, looked at us for an instant, then exploded into the air once more, this time in a more sensible direction. The bird apparently was unhurt. The New York State study reports that alarmed Ruffed Grouse have been timed at speeds up to 47.2 miles per hour. So far as I know, there was nothing to alarm the grouse that the three of us saw, and its speed was much slower. However, had it hit the wall straight on, it most likely would have been another fatality.
In the next incident in early May of 1966 the grouse survived at least the initial impact. Again the time was early evening, and again a loud "thump" took me outside. There stood a Ruffed Grouse, bill agape, unsteadily watching me. It made no effort to fly away and it did not even attempt to walk off. I did not approach closer, for I feared that the bird had suffered internal injuries and I did not want to disturb it. After 10 minutes it walked into one of the aspen bluffs. It is probable, however, in view of the findings of Bump and his associates, that the bird failed to survive. They discovered, at least among captive birds, that even minor injuries may cause death from malnutrition because of a disinclination to eat.

The last of the six incidents is the only one occurring in fall (September, 1968) and the validity of the observation is to be questioned. At dusk I again heard the familiar thump. On going outside, however, I found neither bird nor feathers which could aid in identifying the source of the noise. but I believed it to have been a grouse.

In the past three years I have not noted any flights against our house. Why the cessation of this phenomenon now, and why its sudden onset in 1963 , when throughout the years Ruffed Grouse have been relatively numerous in this local area? Knight (1947), although he agrees with Edminster's' conclusions, may throw some additional light on my observations. He records that the owner of a new house on the edge of a wood had painted it white, with the result that many Ruffed Grouse killed themselves by flying against its walls. The birds, Knight suggests, probably thought that clear sky was ahead of them. The owner then painted his house a dark color, and the accidental deaths stopped. Now, I did paint our house white the summer before the casualties started. The gleaming white boards might have appeared as sky. However, most of the casualties occurred in times of waning light. Furthermore, the house has always been painted white, and no collisions occurred when the house was 
freshly painted twice in the 1940's.

In the late 1930's my older brother observed a Sharp-tailed Grouse (Pedioccetes phasianellus) fly headfirst against an oat-bundle stack in midwinter (with no obvious injury to itself). The bundles were snow-free so that the stack made a sharp contrast with its lighter surroundings. This bird had flown as any grouse typically flies-in a straight line once it had taken off. A grouse may veer in its course, but its stiff-wins ed flight allows for little manoeuvrability. Witness the clicking sounds made by a Ruffed Grouse's wings as they hit against twigs or small branches in the bird's flight through woods. Since the Ruffed Grouse tends to fly close to the ground in its natural treed habitat, it is more likely than other grouse to meet obstacles in its path.

Through the years naturalists and woodsmen have added to our understanding of the Ruffed Grouse's crazy flight but more details of the circum- stances surrounding this curious phenomenon need to be recorded in the future.

\section{LITERATURE CITED}

Allen, A. A. 1928. The Ruffed Grouse investigation: progress report for 1928. Trans. 15th Natl. Game Conf. (Washington, D.C.), 8:3-8.8.

Audiubon, J. J. 1838. (Dover ed., 1967). The iirds of America, Vol. 5. New York.

Bent, A. C. 1932. Life histories of Nortl Anerican gra!linaceous birds. U.S. Natl. Mus. Bull. 162, Washington, D.C.

Bump, G., R. W. Darrow, F. C. Edminster, and W. F. Crissey. 1947. The Ruffer: Grouse: life history, propagation, mallagenent. New Y.sk State C ms. Dept., Albany.

Edminster, F. C. 1947. The Ruffed Grullis, its life story, ecology and management. Macmilin, N $\mathrm{N}, \mathrm{v}$ Yurk.

Forbush, E. H. 1927. Birds of Massachusetts and other New England states, Vol. 2. Berwick and Smith, Norwood, Mass.

Grange, W. B. 1948. Wisconsin grouse problems. Wisconsin Cons. Dept., Madison.

Gross, A. A. 1925. Diseases of the Ruffed Grouse. Science, $62: 55-57$.

Hall, H. M. 1946. The Ruffed Grouse. Oxford Univ. Press, New York.

Knight, J. A. 1947. Ruffed Grouse. Alfred A. Knopf, New York.

\section{ANNUAL MAY-DAY BIRD COUNTS, 1971}

Reports of the May-Day counts will appear in future in the Society's Newsletter, following a decision taken at a meeting of the Board of Directors earlier this year. However, since the counts have appeared regularly in the Blue Jay for a number of years, sumniaries of the 1971 reports submitted by Saskatoon and Regina are presented in this issue. Interested readers are referred to the full accounts which will appear in Newsletter No. 28, Summer 1971.

\section{Annual May-Day Bird Count, Saskatoon, May 14, 1971}

Fifty-nine observers in 11 groups drove 1,243 miles and walked another 30 this year to uncover $37,012+$ birds of 137 species. The species total (far below last year's record 162) is impressive when weather conditions and the scarcity of migrant flycatchers, thrushes, vireos, warblers and sparrows are taken into account.
Another factor was that this year's count was 8 days earlier than in 1970 . The day was cool with brisk NW winds which made it difficult to hear bird calls after 7 a.m.

The April-May migration this year was one of the most erratic in memory. The first migrants arrived earlier than usual. About 10 days prior to the count, migratory movements virtually ceased. Not until May 17 did a fair number of flycatchers, thrushes, vireos and warblers begin to pass through the region.

Records of interest include the huge flocks of Lapland Longspurs, the more than 19,465 individuals representing over half of the total birds counted. The 68 Snow Geese at Brightwater Reservoir were the first recorded since May-day counts began in 1957. All of the hawks seem to have maintained their numbers during the past four years. Short-eared and Long-eared Owls remain scarce after the peak 